IRA International Journal of Management \& Social Sciences ISSN 2455-2267

Vol. 14, Issue 02 (Special Issue) pg. 171-176.

International Conference on Wellbeing: Lifespan Perspectives $\$$ Practices for Sustainable

Communities, 2019.

\title{
Rates of Anxiety and Depressive Symptoms among Female Undergraduate Medical Students at National Medical College and Teaching Hospital
}

Sandesh Sawant ${ }^{1}$, Garima Tripathi ${ }^{2} \&$ Tripti Pal Raman ${ }^{2}$

${ }^{1}$ Department of Psychiatry, National Medical College and Teaching Hospital, Birgunj, Nepal.

${ }^{2}$ Department of Community Medicine National Medical College and Teaching Hospital, Birgunj, Nepal.

DOI: $10.21013 /$ jmss.v14.n2sp.p17

(c) Authors.

Type of Review: Peer Reviewed under the Responsibility of the conference's Scientific Committee.

Disclaimer: The copyright to this work is retained by the authorship. This work contains the opinions 69 views of the authorship solely and the same are not the views or opinions of the IRA. IRA disclaims of any harm or loss caused due to the published content to any party. 


\begin{abstract}
Background: Literature states that Depression and anxiety symptoms carry impairment to medical students, including poor academic performance, drop out, substance abuse and suicide. A high prevalence of anxiety and depression among medical students has been reported worldwide. Higher prevalence is noticed among female students.
\end{abstract}

Aim/Objectives: To study rates of anxiety and depressive symptoms among female undergraduate medical students.

Methods: The present study is a cross-sectional study. The purposive sampling method was used. Duration of study was 6 months. A total number of participants' were100. Self-developed questionnaire and Hospital Anxiety and Depression scale were used.

Results: Findings showed that the mean score of anxiety symptoms was 8.08 ( $\mathrm{SD} \pm 4.07)$. Similarly, the mean score of Depressive symptoms was 4.99 ( $\mathrm{SD} \pm 3.28$ ). Fifty-two per cent of the students rated anxiety symptoms and $25 \%$ of the student rated depressive symptoms between borderline to the abnormal range. Total $9 \%$ of the students reported that they have a family history of mental illness among which $8 \%$ reported borderline to an abnormal range of anxiety however $52 \%$ who had no family history also scored the same range. Similarly, $17 \%$ of the students reported there were life events which were stressful among which $13 \%$ scored borderline to abnormal range anxiety symptoms. Likewise, only $5 \%$ of the students scored borderline to the abnormal range of depressive symptoms.

Conclusion: It was observed that female undergraduate medical students experience both anxiety and depressive symptoms however the percentage of depressive symptoms were less compared to anxiety symptoms. Further studies are required to evaluate the associated factors responsible for depressive and anxiety symptoms.

\title{
INTRODUCTION
}

Prevalence of depression and anxiety in South East Asia were reported to be the highest across the globe i.e. 27\% and $23 \%$ respectively (WHO, 2017). Medical students constitute a vulnerable group for anxiety and depression (Jadoon et al., 2010). In comparison to the general population, medical students reported having a higher prevalence of depression ranging from 2.9 to 38.2\% (Dahlin et al., 2005; Moutinho Coentre and Luisa Figueira, 2015). Experiencing anxiety is reported almost equally or high as compared to depression among medical students (Ahmed et al., 2009; Mancevska et al., 2008). As compared to male medical students female medical students tend to experience more anxiety and depressive symptoms (Alosaimi et al., 2014; Onyishi et al., 2016; Ibrahim and Abdelreheem, 2015). Prevalence of Clinical Depression among Medical Students and Medical Professionals: A Systematic Review Study. Students experience stress due to various adverse situations during undergraduate years of medical study (Wilkinson et al., 2006; Supe, 1998).

Multiple factors like academic pressure, work load, financial hardships, and sleep deprivation were the contributing factors in the development of anxiety and depression (Stewart et al., 1999). First and second-year medical students reported experiencing more stress (Zoccolillo et al., 1986). A negative correlation has been found between stress and academic performance before and during medical school. Factors like anxiety and depression have a temporal correlation with academic performance and have been ranked among the top 10 factors impairing academic performance (ACHA2008).

\section{METHODOLOGY}

The objective of this cross-sectional study was to find out rates of anxiety and depressive symptoms among female undergraduate medical students. Medical students were undertaken from the National Medical College and Teaching Hospital of Birgunj, Nepal. The sample size was calculated using the formula $n=4 \mathrm{pq} / \mathrm{e}^{2}$, where the prevalence of depressive symptom among medical students was taken 6.5\% (Dahlin et al., 2005; Moutinho Coentre, \& Luisa Figueira, 2015). Total numbers of participants were 100. Purposive sampling was done and 20 students from each batch were selected. Self-developed questionnaire and Hospital Anxiety and Depression scale were used which was developed to identify the levels of anxiety and depression. It consists of 14 questions ( 7 each for depression and anxiety) with four-point rating scale ranging from 0-3 (Zigmond, \& Snaith, 1983). The cutoff score for anxiety and depression was 8. A review study of HADS showed Cronbach's alpha for Anxiety ranged from .68 to .93 (mean.83) and for Depression it was .67 to.90 (mean.82) (Bjelland et al., 2002). 
IRA International Journal of Management E' Social Sciences Self developed questionnaire were given out to students who were selected for the study and were asked not to put their identification to maintain confidentiality. Both verbal and written consent was taken. The questionnaire consisted of the following variables: age, country address, family history of mental illness, major life event and year of study. The study period was of 6 months. Data entry and analysis was done using SPSS 20. Descriptive statistics were used for frequency distribution and chi-square test to show the association between the dependent and independent variables.

\section{RESULTS}

In this study, among 100 participants $45 \%$ held Indian nationality and 55\% were Nepalese. The mean age of the participants was 22.05 ( $\mathrm{SD} \pm 1.57$ ). The rate of depressive symptom was $25 \%$ out of which $21 \%$ had a borderline abnormal symptom and only $4 \%$ had an abnormal symptom. The rate of anxiety symptom was $52 \%$ out of which $27 \%$ had borderline and $25 \%$ had abnormal symptoms (Table1). The rate of anxiety symptoms was more in firstyear students (35\%) followed by the fourth and fifth year (30\%) each. There was no depressive symptom in students of the first year and fifth year (Table 2).

It was seen that the association of family history with depressive and anxiety symptoms was significantly high with $\mathrm{p}=0.027$ and 0.001 respectively (Table 3,4 ). Also, change in the environment had a significant association with depressive symptom with $\mathrm{p}$ value $=0.011$, but this association was not seen in anxiety symptoms (Table 5).

\section{Figure 1: Distribution of participants according to nationality.}

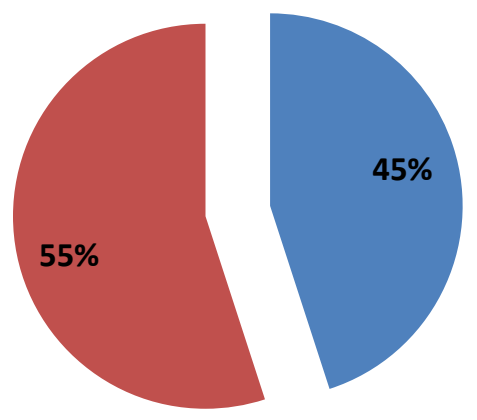

Table 1: Rate of anxiety and depressive symptoms among the participants

\begin{tabular}{|c|c|c|c|}
\hline Symptom & & $\begin{array}{l}\text { Participant } \\
(\mathrm{N}=100)\end{array}$ & $\%$ \\
\hline \multirow{3}{*}{ Depression } & Normal & 75 & 75 \\
\hline & Borderline & 21 & 21 \\
\hline & Abnormal & 4 & 4 \\
\hline & Total & 100 & 100 \\
\hline \multirow{4}{*}{ Anxiety } & Normal & 48 & 48 \\
\hline & Borderline & 27 & 27 \\
\hline & Abnormal & 25 & 25 \\
\hline & Total & 100 & 100 \\
\hline
\end{tabular}


IRA International Journal of Management E' Social Sciences

Table 2: Rate of anxiety and depressive symptoms according to year of study

\begin{tabular}{|c|c|c|c|c|c|c|c|c|c|c|c|c|c|}
\hline Variables & & $\begin{array}{l}1^{\text {st }} \\
\text { year }\end{array}$ & $\%$ & $\begin{array}{l}2^{\text {nd }} \\
\text { year }\end{array}$ & $\%$ & $\begin{array}{l}3^{\text {rd }} \\
\text { year }\end{array}$ & $\%$ & $\begin{array}{l}4^{\text {th }} \\
\text { year }\end{array}$ & $\%$ & $\begin{array}{l}5^{\text {th }} \\
\text { year }\end{array}$ & $\%$ & Total & $\%$ \\
\hline \multirow[t]{3}{*}{ Anxiety } & Normal & 7 & 35 & 11 & 55 & 15 & 75 & 10 & 50 & 5 & 25 & 48 & 48 \\
\hline & Borderline & 6 & 30 & 5 & 25 & 3 & 15 & 4 & 20 & 9 & 45 & 27 & 27 \\
\hline & Abnormal & 7 & 35 & 4 & 20 & 2 & 10 & 6 & 30 & 6 & 30 & 25 & 25 \\
\hline \multicolumn{2}{|c|}{ Total } & 20 & 100 & 20 & 100 & 20 & 100 & 20 & 100 & 20 & 100 & 100 & 100 \\
\hline \multirow[t]{3}{*}{ Depression } & Normal & 14 & 70 & 14 & 70 & 15 & 75 & 17 & 85 & 15 & 75 & 75 & 75 \\
\hline & Borderline & 6 & 30 & 5 & 25 & 3 & 15 & 2 & 10 & 5 & 25 & 21 & 21 \\
\hline & Abnormal & 0 & 0 & 1 & 5 & 2 & 10 & 1 & 5 & 0 & 0 & 4 & 4 \\
\hline \multicolumn{2}{|c|}{ Total } & 20 & 100 & 20 & 100 & 20 & 100 & 20 & 100 & 20 & 100 & 100 & 100 \\
\hline
\end{tabular}

Table 3: Association between depression and its aggravating factors

\begin{tabular}{|c|c|c|c|c|c|c|}
\hline \multicolumn{2}{|c|}{ Variable } & \multicolumn{2}{|c|}{ Depression } & \multirow[t]{2}{*}{ Chi-square } & \multirow[t]{2}{*}{ df } & \multirow[t]{2}{*}{ P-value } \\
\hline & & $\begin{array}{l}\text { Present } \\
\text { (n) }\end{array}$ & $\begin{array}{l}\text { Not Present } \\
\text { (n) }\end{array}$ & & & \\
\hline \multirow[t]{2}{*}{ Age } & $<20$ & 15 & 4 & \multirow[t]{2}{*}{0.987} & \multirow[t]{2}{*}{2} & \multirow[t]{2}{*}{0.61} \\
\hline & $>20$ & 60 & 21 & & & \\
\hline \multirow[t]{2}{*}{ Family History } & Yes & 4 & 5 & \multirow[t]{2}{*}{7.25} & \multirow[t]{2}{*}{2} & \multirow[t]{2}{*}{0.027} \\
\hline & No & 71 & 20 & & & \\
\hline \multirow[t]{2}{*}{ Life Event } & Yes & 12 & 5 & \multirow[t]{2}{*}{0.297} & \multirow[t]{2}{*}{2} & \multirow[t]{2}{*}{0.862} \\
\hline & No & 63 & 20 & & & \\
\hline \multirow[t]{5}{*}{ Year of Study } & 1 st & 14 & 6 & \multirow[t]{5}{*}{6.471} & \multirow[t]{5}{*}{8} & \multirow[t]{5}{*}{0.595} \\
\hline & $2 \mathrm{nd}$ & 14 & 6 & & & \\
\hline & $3 \mathrm{rd}$ & 15 & 5 & & & \\
\hline & 4 th & 17 & 3 & & & \\
\hline & 5 th & 15 & 5 & & & \\
\hline
\end{tabular}

Table 4: Association between anxiety and its aggravating factors

\begin{tabular}{|c|c|c|c|c|c|c|}
\hline \multicolumn{2}{|c|}{ Variable } & \multicolumn{2}{|c|}{ Anxiety } & \multirow[t]{2}{*}{ Chi-square } & \multirow[t]{2}{*}{ df } & \multirow[t]{2}{*}{ P-value } \\
\hline & & $\begin{array}{l}\text { Present } \\
\text { (n) }\end{array}$ & $\begin{array}{l}\text { Not Present } \\
\text { (n) }\end{array}$ & & & \\
\hline \multirow[t]{2}{*}{ Age } & $<20$ & 8 & 11 & \multirow[t]{2}{*}{0.368} & \multirow[t]{2}{*}{2} & \multirow[t]{2}{*}{0.832} \\
\hline & $>20$ & 40 & 41 & & & \\
\hline \multirow[t]{2}{*}{ Family History } & Yes & 1 & 8 & \multirow[t]{2}{*}{14.748} & \multirow[t]{2}{*}{2} & \multirow[t]{2}{*}{0.001} \\
\hline & No & 47 & 44 & & & \\
\hline \multirow[t]{2}{*}{ Life Event } & Yes & 4 & 13 & \multirow[t]{2}{*}{4.948} & \multirow[t]{2}{*}{2} & \multirow[t]{2}{*}{0.084} \\
\hline & No & 44 & 39 & & & \\
\hline \multirow[t]{5}{*}{ Year of Study } & $1 \mathrm{st}$ & 7 & 13 & \multirow[t]{5}{*}{13.293} & \multirow[t]{5}{*}{8} & \multirow[t]{5}{*}{0.102} \\
\hline & 2nd & 11 & 9 & & & \\
\hline & $3 \mathrm{rd}$ & 15 & 5 & & & \\
\hline & 4th & 10 & 10 & & & \\
\hline & 5th & 5 & 15 & & & \\
\hline
\end{tabular}


IRA International Journal of Management E' Social Sciences

Table 5: Association of anxiety and depressive symptoms with change of place

\begin{tabular}{|c|c|c|c|c|}
\hline Variables & & Anxic & & P value \\
\hline Nationality & $\begin{array}{c}\text { Normal } \\
\mathrm{n}(\%)\end{array}$ & $\begin{array}{l}\text { Borderline } \\
\mathrm{n}(\%)\end{array}$ & $\begin{array}{c}\text { Abnormal } \\
\text { n (\%) }\end{array}$ & \multirow{3}{*}{0.06} \\
\hline Nepal & $31(56.4)$ & $15(27.3)$ & $9(16.4)$ & \\
\hline India & $17(37.8)$ & $12(26.7)$ & $16(25.6)$ & \\
\hline \multicolumn{5}{|c|}{ Depression } \\
\hline & $\begin{array}{c}\text { Normal } \\
\mathrm{n}(\%)\end{array}$ & $\begin{array}{c}\text { Borderline } \\
\mathrm{n}(\%)\end{array}$ & $\begin{array}{c}\text { Abnormal } \\
\mathrm{n}(\%)\end{array}$ & \multirow{3}{*}{0.011} \\
\hline Nepal & $47(85.5)$ & $8(14.5)$ & $0(0.0)$ & \\
\hline India & $28(62.2)$ & $13(28.9)$ & $4(8.9)$ & \\
\hline
\end{tabular}

\section{DISCUSSION:}

In this study, it was observed that female undergraduate medical students experience both anxiety and depressive symptoms. However, the percentage of depressive symptoms was less compared to anxiety symptoms in the abnormal range category. The present findings show similar results to the previous literature (Andrade et al., 2001). However, the rate of depressive symptom among the participants in the present study varies from other studies done on the same subject which is probably due to a different scenario. Though, certain consistencies were seen in the respect that the rates were higher than those of the general population (Silva, et. al., 2017; Yadav et al., 2017). The rate of anxiety symptom was more in $1^{\text {st }}$-year student $(35 \%)$ followed by $4^{\text {th }}$ and $5^{\text {th }}$ year $(30 \%)$. Depressive symptoms were observed in $2^{\text {nd }}, 3^{\text {rd }}$ and $4 \mathrm{rth}$ year student during the time of transition from pre-clinical to clinical period and found completely absent in student of the $1^{\text {st }}$ year and $5^{\text {th }}$-year student. The result where $1^{\text {st }}$ and final year experiencing anxiety at a higher level may be due to multiple factors like entering into a new school, increase the level difficulty in course work, staying away from home, exam pressure, and so on. Likewise increased anxiety among 5th-year students may be the result of final year pressure appearing in the exam. Similar results were found in other literature where the rates of anxiety were higher and varied but depressive symptoms were mainly seen in students during their transitional phase (Moutinho et al., 2015; Mayer et al ., 2016). Recent negative life event was also found more likely to be associated with depression. Also, students coming from abroad had a harder time adjusting to a new environment and fall into depression more easily.

Further studies are required to evaluate the associated factors responsible for depressive and anxiety symptoms in details that may contribute to the development of anxiety and depressive symptoms.

\section{Conclusion}

Depression and anxiety symptoms were quite common among female medical students. Among the factors related, family history had a strong association with both the anxiety and depressive symptoms. Participants coming from abroad had a harder time adjusting to the environment which also contributed to the development of depression.

\section{References}

[1]. Ahmed, I., Banu, H., Al-Fageer, R., \& Al-Suwaidi, R. (2009). Cognitive emotions: depression and anxiety in medical students and staff. Journal of critical care, 24(3), e1-e7.

[2]. Alosaimi, F. D., Al-Sultan, O. A., Alghamdi, Q. A., Almohaimeed, I. K., \& Alqannas, S. I. (2014). Gender-specific differences in depression and anxiety symptoms and help-seeking behaviour among gastroenterology patients in Riyadh, Saudi Arabia. Neurosciences, 19(3), 203.

[3]. American College Health Association. (2008). American College Health Association-National College Health Assessment spring 2007 reference group data report (abridged). Journal of American college health: J of ACH, 56(5), 469.

[4]. Andrade, L., Gorenstein, C., Vieira Filho, A. H., Tung, T. C., \& Artes, R. (2001). Psychometric properties of the Portuguese version of the State-Trait Anxiety Inventory applied to college students: factor analysis and relation to the Beck Depression Inventory. Brazilian Journal of Medical and Biological Research, 34(3), 367-374.

[5]. Bjelland, I., Dahl, A. A., Haug, T. T., \& Neckelmann, D. (2002). The validity of the Hospital Anxiety and Depression Scale: an updated literature review. Journal of psychosomatic research, 52(2), 69-77.

[6]. Dahlin, M., Joneborg, N., \& Runeson, B. (2005). Stress and depression among medical students: A cross-sectional study. Medical education, 39(6), 594-604

[7]. Ibrahim, M. B., \& Abdelreheem, M. H. (2015). Prevalence of anxiety and depression among medical and pharmaceutical students in Alexandria University. Alexandria Journal of Medicine, 51(2), 167-173.

[8]. Jadoon, N. A., Yaqoob, R., Raza, A., Shehzad, M. A., \& Zeshan, S. C. (2010). Anxiety and depression among medical students: a cross-sectional study. JPMA. The Journal of the Pakistan Medical Association, 60(8), 699-702. 
IRA International Journal of Management E' Social Sciences

[9]. Mancevska, S., Bozinovska, L., Tecce, J., Pluncevik-Gligoroska, J., \& Sivevska-Smilevska, E. (2008). Depression, anxiety and substance use in medical students in the Republic of Macedonia. Bratislavske lekarske listy, 109(12), 568572.

[10]. Mayer, F. B., Santos, I. S., Silveira, P. S., Lopes, M. H. I., de Souza, A. R. N. D., Campos, E. P., ... \& Almeida, R. (2016). Factors associated to depression and anxiety in medical students: a multicenter study. BMC medical education, 16(1), 282.

[11]. Moutinho Coentre, R., \& Luisa Figueira, M. (2015). Depression and suicidal behavior in medical students: a systematic review. Current Psychiatry Reviews, 11(2), 86-101.

[12]. Onyishi, M., Talukdar, D., Sanchez, R., Olaleye, A. O., \& Medavarapu, S. (2016). Prevalence of Clinical Depression among Medical Students and Medical Professionals: A Systematic Review Study

[13]. Silva, V., Costa, P., Pereira, I., Faria, R., Salgueira, A. P., Costa, M. J., ... \& Morgado, P. (2017). Depression in medical students: insights from a longitudinal study. BMC medical education, 17(1), 184.

[14]. Stewart, S. M., Lam, T. H., Betson, C. L., Wong, C. M., \& Wong, A. M. P. (1999). A prospective analysis of stress and academic performance in the first two years of medical school. Medical education.

[15]. Supe, A. N. (1998). A study of stress in medical students at Seth GS Medical College. Journal of postgraduate medicine, 44(1), 1.

[16]. Wilkinson, T. J., Gill, D. J., Fitzjohn, J., Palmer, C. L., \& Mulder, R. T. (2006). The impact on students of adverse experiences during medical school. Medical Teacher, 28(2), 129-135.

[17]. World Health Organization. (2017). Depression and other common mental disorders: global health estimates.

[18]. Yadav, R., Gupta, S., \& Malhotra, A. K. (2017). A cross-sectional study on depression, anxiety and their associated factors among medical students in Jhansi, Uttar Pradesh, India. International Journal Of Community Medicine And Public Health, 3(5), 1209-1214.

[19]. Zigmond, A. S., \& Snaith, R. P. (1983). The hospital anxiety and depression scale. Acta Psychiatrica Scandinavica, 67(6), 361-370.

[20]. Zoccolillo, M., Murphy, G. E., \& Wetzel, R. D. (1986). Depression among medical students. Journal of affective disorders, 11(1), 91-96. 